\title{
Evaluation of the benthic macroinvertebrate distribution in a stream environment during summer using biotic index
}

\author{
*S. Girgin \\ Department of Biology, Faculty of Gazi Education, Gazi University, Teknikokullar, Ankara, Turkey \\ Received 19 August 2009; revised 25 October 2009; accepted 2 November 2009; available online 1 December 2009
}

\begin{abstract}
The purpose of this study is to evaluate the benthic macroinvertebrate distribution in the Keşap Stream (in the Eastern Black Sea Region of Turkey) for the summer period using biotic index. The water quality was assessed through the application of the Belgian biotic index. For this purpose, benthic macroinvertebrate sampling was performed in six sites along the Keşap Stream in the summer period, in July 2007. The distribution of dominant genera of the sites was evaluated according to water quality. According to the Belgian biotic index, II, III and IV water quality classes (slightly, moderately and heavily polluted, respectively) were determined in the stream. In addition, diversities of benthic macroinvertebrates in six sites were calculated. The biotic index values are found also consistent with the diversity values. Especially, in areas of the stream after industrial facilities water quality decreased. However, very heavy pollution was not observed accord to the biotic index values. It was found that Ephemeroptera was the dominant major taxon in all sampling sites. As a result of this biological evaluation, Ephemeroptera were concluded to be the most common taxa in the stream and the ephemeropterans, Potamanthus, Baetis and Ephemerella were dominant genera in the conditions of slightly, moderately and heavily polluted.
\end{abstract}

Keywords: Biological assessment ; Biological indicators; Diversity; Pollution; Water quality

\section{INTRODUCTION}

Benthic macroinvertebrates constitute an important part of aquatic organisms in aquatic environments. The aquatic organisms are exposed to anthropogenic disturbance as well as natural changes in their habitats which are to be responded in various ways. Therefore, aquatic organisms also have an important role in biomonitoring (Rosenberg and Resh, 1993; Kazanci et al., 1997; Mooraki et al. 2009). Benthic macroinvertebrates are often preferred for biological monitoring. Benthic macroinvertebrates are good indicators of aquatic environments. Various studies with benthic macroinvertebrates have been performed using their indicator features in Turkey (Kazanci and Girgin 1998; Girgin et al. 2003; Dügel and Kazanci, 2004; Kazanci and Türkmen, 2008; Kazanci et al. 2008a).

There are various indices to determine water quality using benthic macroinvertebrates. One of them is the Belgian biotic index (BBI). It combines the indice biotique from France with the sampling method used for the trent biotic index in the UK (De Pauw and Vanhooren, 1983; Metcalfe, 1989).

*Corresponding Author Email: sonmez.girgin@gmail.com Tel./Fax: +90 03122028211
In Turkey, the first use of biotic indices for streams was performed by DSI (State Water and Hydraulic Works) together with British experts in 1992. For this purpose, a project was carried out in the Seyhan and Sakarya basins. In this study, the BMWP (biological monitoring working party) score system and Trent Biotic Index (TBI) were used (DSI, 1992). Then, in a project carried out at the Köycegiz-Dalyan Nature Reserve Area, the application of the BBI was performed for the first time in Turkey. Also, for streams in that region, an index was created based on the Turkish fauna for the first time in Turkey (Kazanci, 1993). Many studies have been done in several streams of Turkey using biotic index (Girgin and Kazanci, 1997; Girgin et al., 1997; Kazanci et al., 1997). In recent years, studies of this type are continuing to grow in Turkey (Duran et al., 2003; Kalyoncu et al., 2008; Kazanci et al., 2008b; Türkmen and Kazanci, 2008).

Coastal areas and inland waters are affected negatively from human impact, agricultural and industrial activities (Alam et al., 2007; Imandoust and Gadam, 2007; Nouri et al., 2008; Igbinosa and Okoh, 2009; Pejman et al., 2009). But the Kesap Stream that 
flows into the Black Sea is currently not under the pressure of intensive industrialization and urbanization. This research aims to determine the distribution of the benthic macroinvertebrates and the relationships between their distribution and the water quality of the Kesap Stream using the Belgian biotic index in the summer period, July 2007. In this stream, such a study has not been performed previously. Therefore, this is important as a preliminary study for the stream flowing into the Black Sea.

\section{MATERIALS AND METHODS}

Site description

The Kesap Stream is located in the town of Kesap, in Giresun, in the eastern Black Sea Region of Turkey. The main branch of the stream rises from Karadag, which is $1200 \mathrm{~m}$ in elevation and runs parallel to the sea. One of the tributaries of the stream rises from the hills of the Düzkestane district of Yivdincik village, passes through the Düzkestane valley and connects with the Karabulduk Creek under the Karadere village. The Kesap Stream with all branches is approximately 50 $\mathrm{km}$ in length. There is a hydroelectric power plant on the stream. The Kesap Stream passes through the town of Kesap and flows into the Black Sea. According to official website of T.C. Kesap Kaymakamligi, the weather is hot in summer and warm in winter in Kesap. There is no significant difference between day and night temperatures. While the hottest month is July with a maximum of $30^{\circ} \mathrm{C}$, the coldest month is January with a minimum of $-2^{\circ} \mathrm{C}$. Annual precipitation is high and humidity is $75 \%$ (T.C. Kesap Kaymakamilgi, 2006)

Six sampling sites were established along the stream:

Sampling site 1 (40 54' 062" N, 38 31' 267" E): Inlet of fertilizer plant (furthest sampling site to the sea).
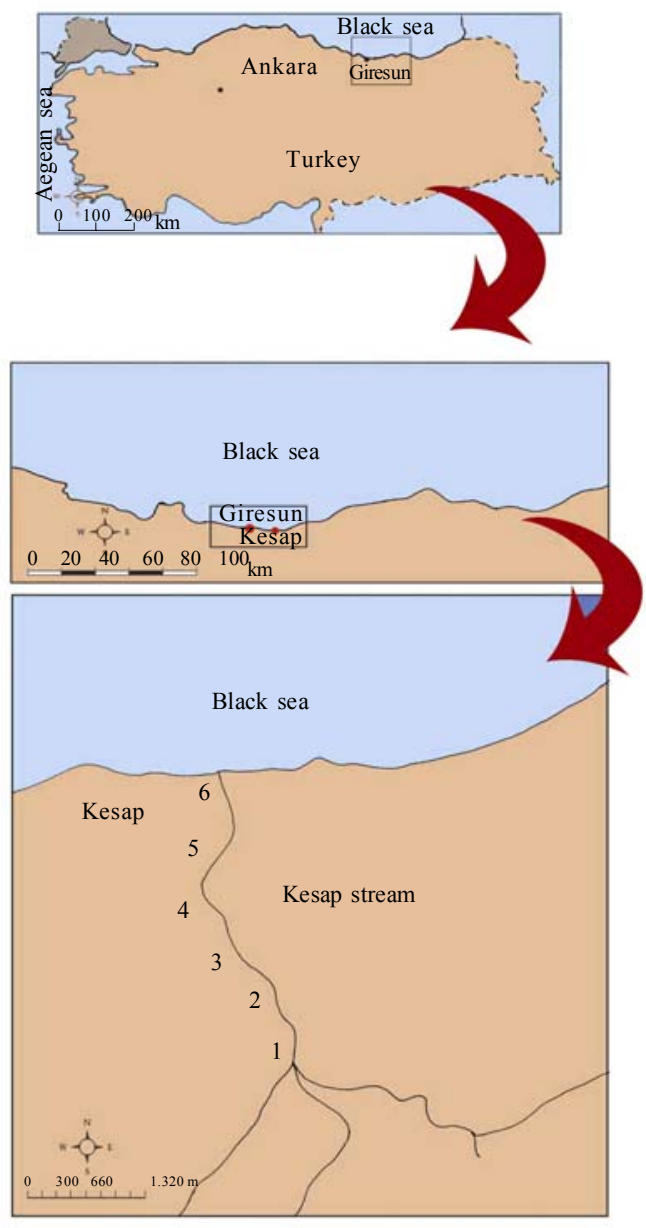

Fig. 1: The study area 
The stream bed consists of coarse gravels, stones and sand. It is surrounded by settlement and fields. It is upstream site.

Sampling site 2 (4054' 143" N, 38 31' 265" E): Outlet of fertilizer plant. The stream bed consists of coarse gravel and stones. It is surrounded by settlement and fields.

Sampling site 3( $\left.40^{\circ} 54^{\prime} 367^{\prime \prime} \mathrm{N}, 38^{\circ} 31^{\prime} 055^{\prime \prime} \mathrm{E}\right)$ : Inlet of sawmill. The stream bed consists of pebbles. It is surrounded by settlement and fields."

Sampling site 4 (4054' 508" N, 38 30' 939" E): Outlet of sawmill. The stream bed consists of pebbles and stones. It is surrounded by settlement and fields.

Sampling site 5 ( $40^{\circ} 54^{\prime} 649^{\prime \prime}$ N, 38 30' 858" E): Inlet of slaughterhouse. The stream bed consists of pebbles, silt and stones. It is surrounded by settlement, hazelnut farms and fields.

Sampling site 6(4054' 861" N, 38 30' 999" E): Outlet of slaughterhouse (nearest sampling site to the sea). The stream bed is composed mainly of clay, silt and pebbles. It is surrounded by settlement. It is downstream site.

The sampling sites are shown on the map (Fig. 1).

\section{Sampling}

Benthic macroinvertebrates were collected from upstream to downstream sites of the main branch of the Kesap Stream in July 2007. For sampling, six stations were chosen according to pollutants. The benthic macroinvertebrates were sampled with the kicking method for $10 \mathrm{~min}$, with a D-framed kick net. Specifically, fast flowing parts of the stream were selected during the sampling. However, the sampling was done from different habitats that reflect all the features of the stations (e.g. slow flowing and stagnant waters, gravelly, stony, sandy, stream-bank vegetation, light or shaded areas).

Samples were kept in $80 \%$ ethyl alcohol and were sorted from the detritus in the laboratory. An Olympus CX21 binocular microscope and Phywe stereo microscope were used for the identification of the specimen.

\section{Diversity and biotic indices}

The diversity was calculated with Shannon's formula (Southwood, 1991). The Belgian biotic index was used to determine water quality. In the Belgian biotic index, in comparison with most other assessment methods, the organisms are only identified at family or genus level and not on a species level (Metcalfe, 1989). For this reason, genus or family levels were prefered as identification levels.

\section{RESULTS AND DISCUSSION}

In July 2007, from the 6 sampling sites, a total of 123 individuals belonging to 20 macrobenthic genera were determined, representing the major taxa Mollusca, Ephemeroptera, Plecoptera, Odonata, Coleoptera, Trichoptera and Diptera (Table 1).

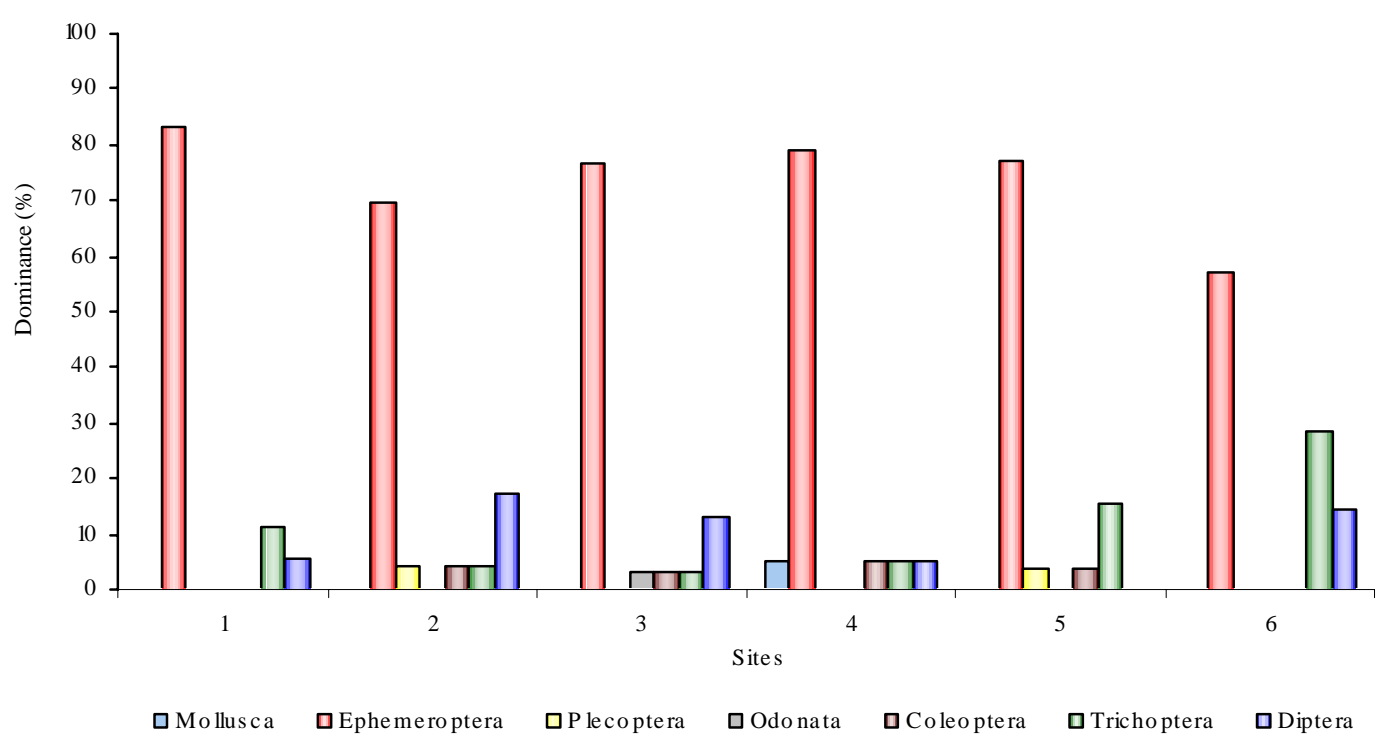

Fig. 2: Distribution of the major taxa and their dominance (\%) values in the Kesap Stream 
Table 1: Abundance, dominance (\%) values of benthic macroinvertebrates of Kesap Stream and their diversities and biotic index values (in each sampling site, dominant taxa have been marked as bold)

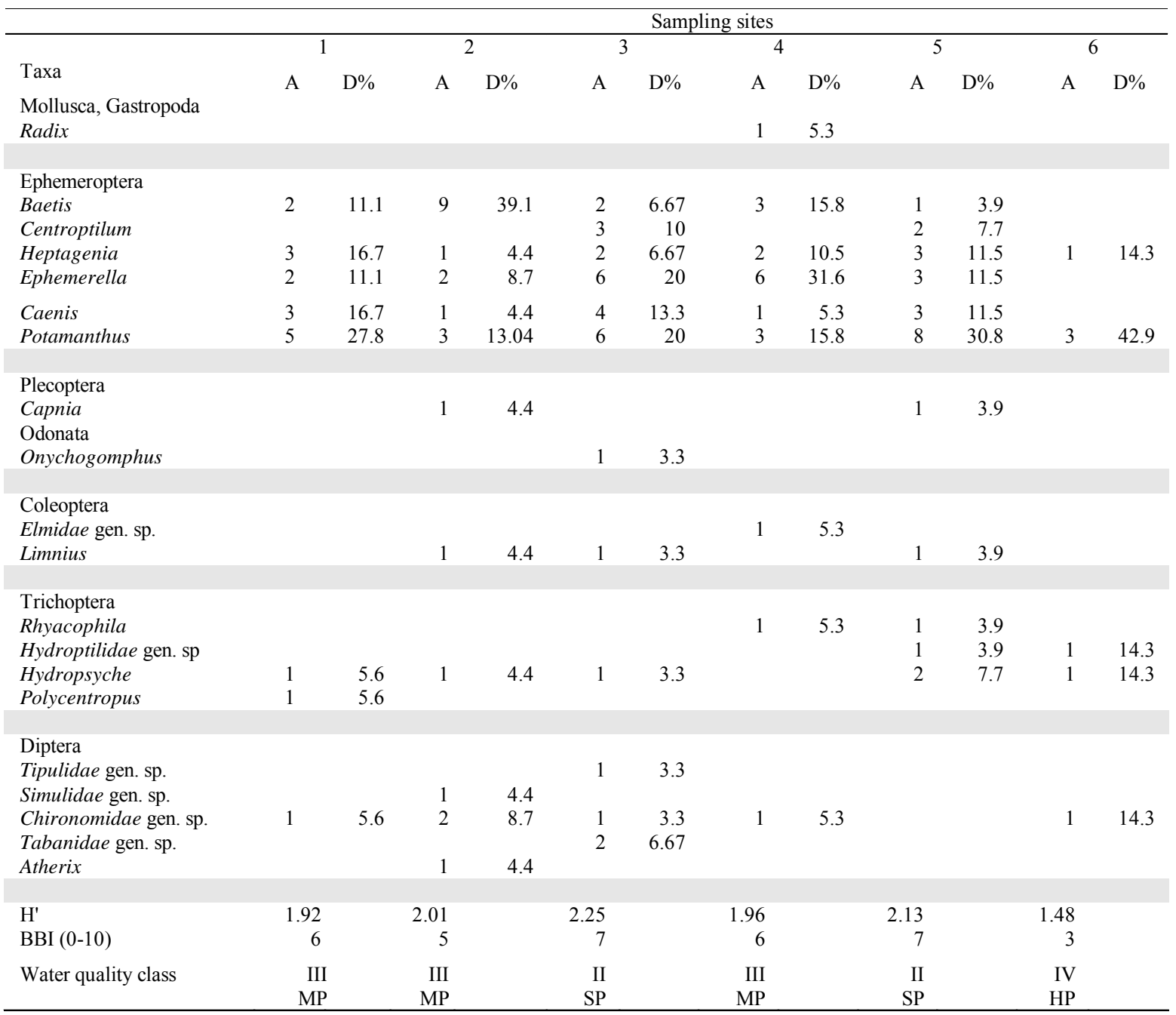

A: abundance; D\%: dominance \%; H': Shannon's diversity index; BBI: Belgian

Biotic index; MP: moderately polluted; SP: slightly polluted; HP: heavily polluted

Dominant major taxa are shown in Fig. 2. As it is shown in Fig. 2, Ephemeroptera was the predominant taxon at all of the sampling sites (6 genera representing $30 \%$ of the fauna and $75.6 \%$ of the total abundance). Diptera, with 5 species, was the second most important taxon $(25 \%$ of the fauna but only $8.9 \%$ of the total abundance) (Table 1). The Ephemeropterans, Potamanthus and Ephemerella were co-dominant genera in sampling site 3 . Each of them constituted the major benthic macroinvertebrat fauna, comprising $20 \%$ of total benthic macroinvertebrates, followed by Ephemeropteran, Caenis (13.3\%). In the $4^{\text {th }}$ station, the ephemeropteran, Ephemerella constituted the major benthic macroinvertebrate fauna, comprising $31.6 \%$ of total benthic macroinvertebrates, followed by ephemeropterans, Baetis and Potamanthus (each of them $15.8 \%$ ). Potamanthus was dominant also in sampling sites 1,5 and 6 . It constituted the major benthic macroinvertebrates, comprising $27.8 \%, 30.8$ $\%, 42.9 \%$ (respectively) of total benthic macroinvertebrates, followed by ephemeropterans, Heptagenia and Caenis (each of them $16.7 \%$ ) in sampling site 1, the ephemeropterans, Heptagenia, Ephemerella and Caenis (each of them $11.5 \%$ ) in 
sampling site 5 and the ephemeropteran, Heptagenia, trichopterans, Hydroptilidae gen. sp. and Hydropsyche, dipteran, Chironomidae gen. sp. (each of them $14.3 \%$ ) in sampling site 6 . In the second station, Ephemeropteran, Baetis was dominant. It constituted the major benthic macroinvertebrat fauna, comprising $39.1 \%$ of total benthic macroinvertebrates, followed by ephemeropteran, Potamanthus (13.04 \%) (Table 1). Diversity index was also applied in the sampling sites. According to the Shannon's diversity index, the index value is between 1 and 3 in moderate polluted streams (Mason, 1981). The diversity values, which were found in this study, ranged from 1.48 (in the $6^{\text {th }}$ sampling site) to 2.25 (in the $3^{\text {rd }}$ sampling site) (Table 1).

The biological assessment of surface water quality is based on a qualitative sampling of the aquatic macroinvertebrate fauna and the use of the biotic index to express the biological result (De Pauw and Vanhooren, 1983). The BBI allows the classification of streams in terms of unpolluted and polluted sites. The water quality classes are between 0 (very heavily polluted) and 10 (unpolluted or slightly polluted) according to this index.

BBI values and water quality classes of the Kesap Stream have been indicated on Table 1. The lowest biotic index value was determined as 3 (water quality class IV) in sampling site 6 , the outlet of the slaughterhouse. It is the most downstream site, nearest to the sea and it is a heavily polluted site. The highest biotic index value was determined as 7 (water quality class II) in sampling sites 3 and 5, the inlet of the sawmill and the inlet of the slaughterhouse respectively. They are slightly polluted sites. The biotic index values are also consistent with the diversity values. While both of sampling sites 3 and 5 had the highest biotic index and diversity index values, sampling site 6 had the lowest biotic index and diversity index values among the other sites of the Kesap Stream (Table 1). Potamanthus were the dominant taxon in sampling sites $1,3,5$ and 6 , but its abundance was lower in the sampling site 6 than the others. In addition, Ephemerella and Potamanthus were co-dominant genera in sampling site 3. Potamanthus spp. are tolerant of organic pollution and they prefer betamesosaprobic, alpha-mesosaprobic, and polysaprobic environments (Rosenberg and Resh, 1993; Kazanci et al., 2008a). This study is supported by the foregoing. Potamanthus was found in slightly (sampling sites 3 and 5), moderately (sampling site 1) and heavily (sampling site 6) polluted sites of the Kesap Stream. Ephemerella species are indicators of oligosaprobic beta-mesosaprobic environments (Bauerfeind et al., 1995). The species of Ephemerella are indicators for slight and moderate organic pollution (oligosaprobic beta mesosaprobic) (Rosenberg and Resh, 1993). The study findings are supported by the foregoing. In the Kesap Stream, Ephemerella was found in slightly and moderately polluted sampling sites 1, 2, 3, 4 and 5 and except the heavily polluted site 6 .

As a result of this biological evaluation, Ephemeroptera were reported as the most common taxa in the stream and the ephemeropterans, Potamanthus, Baetis and Ephemerella were dominant genera. In addition, it is said that water quality of the sites in the summer period were slightly or moderately polluted except for station 6. Station 6 had heavy pollution. Especially, in areas of the stream after industrial facilities (sampling sites 2, 4, 6), water quality decreased. However, very heavy pollution was not observed accord to the biotic index values.

\section{ACKNOWLEDGEMENTS}

The author would like to thank the undergraduate students Fatma Türkmenoglu and Medeya Boranbayeva for their assistance in the field work and Associate Professor Dr. Ihsan Çiçek from the Ankara University Faculty of Letters for help regarding the map.

\section{REFERENCES}

Alam, Md. J. B.; Islam, M. R.; Muyen, Z.; Mamun, M.; Islam, S., (2007). Water quality parameters along rivers. Int. J. Environ. Sci. Tech., 4 (1), 159-167 (9 pages).

Bauerfeind, E.; Moog, O.; Weichselbaumer, P., (1995). Ephemeroptera, in: Moog O. (Ed.), Fauna Aquatica Austriaca. Lieferung 1995, 2002. Wasserwirtschaftskataster, Bundesministerium für Land - und Forstwirtschaft, Umwelt und Wasserwirtschaft, Wien.

De Pauw, N.; Vanhooren, G., (1983). Method for biological quality assessment of watercourses in Belgium. Hydrobiologia, 100 (1), 153-168 (16 pages).

DSI, (1992). Sakarya ve Seyhan Havzalarinda kirlenme durumlarinin incelenmesi ve bu havzalarda kalite sinirlarinin tespiti projesi, DSI Genel Müdürlügü Yayinlari, Ankara.

Dügel, M.; Kazanci, N., (2004). Assessment of water quality of the Büyük Menderes River (Turkey) by using ordination and classification of macroinvertebrates and environmental variables. J. Freshwater Eco., 19 (4), 605-612 (8 pages).

Duran, M.; Tüzen, M.; Kayim, M., (2003). Exploration of biological richness and water quality of stream Kelkit, TokatTurkey. Fresenius Envir. Bull., 12 (4), 368-375 (8 pages).

Girgin, S.; Kazanci, N., (1997). Kirmir Çayi'nin Su Kalitesi Üzerine Bir Arastirma, Istanbul Su ve Çevre Sempozyumu'97 Bildiri Kitabi. 339-346, Istanbul. 
Girgin, S.; Kazanci, N.; Dogan, O., (1997). A new approach to the irrigation water quality criteria in Turkey: Ankara Stream, International Conference on "Water management, salinity and pollution control towards sustainable irrigation in the Mediterranean Region. Vol. II Water Quality and Pollution Control. 43-54 Bari, Italy.

Girgin, S.; Kazanci, N.; Dügel, M., (2003). Ordination and classification of macroinvertebrates and environmental data of a stream in Turkey. Water Sci. Tech., 47 (7-8), 133-139 (7 pages).

Igbinosa, E. O.; Okoh, A. I., (2009). Impact of discharge wastewater effluents on the physico-chemical qualities of a receiving watershed in a typical rural community, Int. J. Environ. Sci. Tech., 6 (2), 175-182 (8 pages).

Imandoust, S. B.; Gadam, S. N., (2007). Are people willing to pay for river water quality, contingent valuation, Int. J. Environ. Sci. Tech., 4 (3), $401-408$ (8 pages).

Kalyoncu, H.; Yorulmaz, B.; Barlas, M.; Yildirim, Z. M.; Zeybek, M., (2008), Aksu Cayi’nin Su Kalitesi ve Fizikokimyasal Parametrelerinin Makroomurgasiz Çesitliligi Üzerine Etkisi, Firat Univ. Fen ve Müh. Bil. Dergisi., 20 (1), 23-33 (11 pages).

Kazanci, N., (1993). Protection of Environment and Nature in Köyceðiz-Dalyan, Final Report of Hydrobiological Subproject (GTZ) GmbH. Darmstadt, 229.

Kazanci, N.; Girgin, S.; Dügel, M.; Oguzkurt, D., (1997). Akarsularin çevre kalitesi yönünden degerlendirilmesinde ve izlenmesinde biyotik indeks yöntemi, in: Kazanci, N., (Ed.) Türkiye Iç Sulari Ara ${ }^{\circ}$ tirmalari Dizisi II, Imaj Press, Ankara. 100

Kazanci, N.; Girgin, S., (1998). Distribution of Oligochaeta species as bioindicators of organic pollution in Ankara Stream and their use in biomonitoring, Turk. J. Zool., 22 (1), 8387 (5 pages).

Kazanci, N.; Dügel, M.; Girgin, S., (2008a). Determination of indicator genera of benthic mactoinvertebrate communities in running waters in western Turkey. Rev. Hydrobio., 1 (1), 1-16 (16 pages).

Kazanci, N.; Türkmen, G., (2008). Yedigöller Milli Parki (Bolu) Ephemeroptera (Insecta) faunasi üzerine bir arastirma: su kalitesi ve referans habitat özellikleri. Rev. Hydrobio., 1 (1), 53-71 (19 pages).

Kazanci, N.; Türkmen, G.; Ertunç, Ö.; Gültutan, Y.; Ekingen, P.; Öz, B., (2008b). A research on water quality of Kelkit stream using benthic macroinvertebrates and physicochemical variables, Rev. Hydrobio., 1 (2), 145-160 (16 pages).

Mason, C. E., (1981). Biology of freshwater pollution. Longman House, London, 249.

Metcalfe, J. L., (1989). Biological water quality assessment of running waters based on macroinvertebrate communities: History and present status in Europe. Environ. Pollut., 60 (1-2), 101-139 (39 pages).

Mooraki, N.; Esmaeli Sari, A.; Soltani, M.; Valinassab, T., (2009). Spatial distribution and assemblage structure of macrobenthos in a tidal creek in relation to industrial activities, Int. J. Environ. Sci. Tech. 6 (4), 651-662 (12 pages).

Nouri, J.; Karbassi, A. R.; Mirkia, S., (2008). Environmental Management of coastal regions in the Caspian Sea, Int. J. Environ. Sci. Tech. 5 (1), 43-52 (10 pages).

Pejman, A. H.; Nabi Bidhendi, G. R.; Karbassi, A. R.; Mehrdadi, N.; Esmaeili Bidhendi, M., (2009). Evaluation of spatial and seasonal variations in surface water quality using multivariate statistical techniques, Int. J. Environ. Sci. Tech. 6 (3) 467-476 (10 pages).

Rosenberg, D.; Resh, V., (1993). Freshwater Biomonitoring and Benthic Macroinvertebrates. Chapman and Hall. New York.

Southwood, T. R. E., (1991). Ecological methods, (Chapman and Hall, London), 523.

T. C. Kesap Kaymakamligi. (2006). Official Website. http:// www.kesap.gov.tr/default.asp

Türkmen, G.; Kazanci, N., (2008). Bolu Ili'ndeki bazi akarsularin referans istasyonlarinin saprobik indeks kullanilarak su kalitelerinin degerlendirilmesi, Rev. Hydrobio., 1 (2), 93-118 (26 pages). 